\title{
PENGARUH STATUS GIZI TERHADAP KEJADIAN TB PARU PADA ANAK USIA 1-5 TAHUN YANG TELAH MENDAPATKAN IMUNISASI BCG DI RSU IMELDA PEKERJA INDONESIA TAHUN 2016
}

\author{
Rahmawani Fauza \\ STIKes Imelda Medan, Indonesia
}

\section{Article Info}

ABSTRACT

Tuberculosis (TB) in children is often undiagnosed from those born to 15 years of age because of limited access to health services or because the treating health worker is not ready to recognize the signs and symptoms of TB. Factors causing TB are Immunization Status, Environment, and contact with TB sufferers / family history of TB disease. This type of research is a case control, which was carried out

\section{Keywords:}

Nutritional Status Incidence of pulmonary $\mathrm{TB}$ Children aged 1-5 years BCG immunization at the Imelda Workers' Hospital in Medan. The population in this study were 33 people and the sample used was the total population consisting of 33 case groups and 33 control groups. Data analysis in this study consisted of unvariate analysis, bivariate analysis with chisquare. The results showed that nutritional status influences the incidence of pulmonary TB in children aged 1-5 years who have received $\mathrm{BCG}$ immunization at the Imelda Indonesian Workers Hospital in Medan with a p value $<0.05$, OR value $=5.812(95 \%$ CI $=1.148-29.436$ ) meaning that children with abnormal nutritional status are 5.8 times more at risk of developing lung infections compared to children whose nutritional status is abnormal. It is recommended for health workers to provide information about the signs and symptoms of pulmonary TB, prevention of pulmonary $\mathrm{TB}$ infection, as well as providing nutritious food for the fulfillment of nutrients in children to increase children's endurance through counseling or counseling.

This is an open access article under the CC BY-SAlicense.

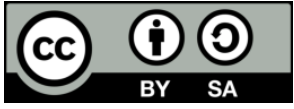

\section{Corresponding Author:}

Rahmawani Fauza,

Program Studi D-III Kebidanan,

STIKes Imelda Medan,

Jl. Bilal No. 52 Kelurahan Pulo Brayan Darat I Kecamatan Medan Timur, Medan - Sumatera Utara.

Email: rahmawani.29@gmail.com

\section{INTRODUCTION}

Dalam laporan WHO tahun 2013 diperkirakan terdapat 8,6 juta kasus TB pada tahun 2012, 75\% diantaranya pasien berada diwilayah Afrika dengan proporsi kasus TB pada anak mecapai 6\% (530.000 anak) pertahunnya atau sekitar $8 \%$ penyebab kematian pada anak disebabkan oleh TB (Kemenkes RI, 2014). Pada tahun 2014 terdapat 9,6 juta penduduk dunia terinfeksi kuman TB (WHO, 2015). Pada tahun 2014, jumlah 
kasus TB paru terbanyak juga berada pada wilayah Afrika (37\%), wilayah Asia Tenggara (28\%), dan wilayah Mediterania Timur (17\%) (WHO, 2015).

Di negara-negara maju seperti Eropa dan Amerika Serikat, TB Paru relatif mulai menurun. Dalam urutan penyakit-penyakit yang disusun menurut frekuensi, baik morbiditas maupun mortalitas, TB Paru menduduki tempat yang jauh lebih rendah dibanding penyakit-penyakit seperti kanker dan kelainan-kelainan kardiovaskular. Hal ini adalah berkat tingginya standar hidup. Diberbagai Negara maju penyakit TB Paru dikatakan sudah dapat dikendalikan, meski peningkatan angka HIV merupakan ancaman potensial terhadap terjadinya kembali TB Paru dinegara maju. Diperkirakan angka kejadian TB Paru di Negara maju hanya 10 hingga 20 kasus per 100.000 penduduk, sedangkan angka kematian hanya berkisar antara 1 hingga 5 kematian per 100.000 penduduk. Di Asia terdapat 110 kasus per 100.000 penduduk, namun mengingat penduduk Asia lebih besar dibandingkan dengan Afrika, maka jumlah absolut yang terkena TB Paru di benua Asia 3,7 kali lebih banyak dari pada Afrika (Achmadi, 2008)

Di beberapa negara berkembang, 10-15\% dari morbiditas berbagai penyakit anak dibawah umur 6 tahun adalah penyakit TB Paru (Rab, 2010). Sedangkan di Indonesia pada tahun 2009 kasus penularan TB Paru menurun mencapai jumlah 528.063 jiwa untuk semua kasus TB Paru dan 236.029 untuk kasus TBC BTA positif, akan tetapi angka kematian naik menjadi 91.368 jiwa. Pada tahun 2010-2011 terdapat 1.840 kasus penyakit TB Paru yang menular pada anak di wilayah kabupaten Bandung (Imarruah, 2014).

Berdasarkan laporan badan kesehatan dunia tahun 2016 tentang TB (Global TB Report 2016) Indonesia berada pada peringkat kedua dalam jumlah kasus TB setelah India. Namun jika dilihat dari data jumlah kasus per 100.000 penduduk, Indonesia menduduki peringkat pertama didunia. Pada tahun 2016 kasus TB paru di Indonesia mencapai 395 per 100.000 penduduk atau mencapai 1.020 .000 penduduk yang terjangkit TB, dengan angka kematian TB mencapai 100.000 penduduk (40 per 100.000 penduduk). Oleh karenanya organisasi kesehatan dunia (WHO) yang tertuang dalam Suitainable Development Goal's (SDGs) dan End TB Strategy menetapkan target pada tahun 2030 dan 2035 penurunan kasus TB sebesar $80 \%$ dan kematian akibat TB menurun hingga 90\% dari angka insiden dan angka kematian TB pada tahun 2016 (UGM, 2017)

Menurut Riskesdas (2013), di Indonesia dari 1.027.763 orang Anggota Rumah Tangga (ART) terdapat $0,4 \%$ penderita TB paru, dan penyumbang TB Paru terbesar adalah provinsi Jawa Barat sebanyak 0,7\% dari jumlah penderita TB di Indonesia. Menurut Dinas Kesehatan Provinsi Sulawesi Utara (2012), Case Detection Rate TB paru di Indonesia per Juni 2012 terdapat sekitar 60,81\% kasus TB Paru di Sulawesi Utara dan angka ini menunjukkan kasus tertinggi di seluruh provinsi di Indonesia. Menurut penelitian Pernanda (2012), kejadian TB Paru di RSUD Panembahan Senopati bantul DIY sebanyak 50\% terdapat kasus TB Paru, $38 \%$ diantaranya tidak mendapat imunisasi BCG dan $12 \%$ telah mendapat imunisai BCG. Sedangkan menurut penelitian (Susanto dkk, 2012) kejadian TB Paru di Puskesmas Tuminting Manado terdapat 45\% kasus TB paru, $41 \%$ diantaranya tidak mendapat imunisasi BCG dan $4 \%$ telah mendapatkan imunisasi BCG.

Pada tahun 2013, angka kejadian TB Paru di Sumatera Barat sebanyak 0,2\% dari jumlah kasus TB Paru di Indonesia. Angka kejadian TB Paru di Sumatera Barat terus mengalami peningkatan. Pada tahun 2010 ditemukan banyaknya kasus TB Paru yang tersebar dalam 19 kabupaten/kota dalam Propinsi Sumatera Barat termasuk Kota Padang. Kota Padang sebagai ibu kota Provinsi Sumatera Barat merupakan salah satu kabupaten/kota yang menyumbang angka kejadian TB Paru yang cukup tinggi yaitu sebanyak 927 kasus (Kemenkes, 2013).

Pada anak TB mencapai 15\% - 40\% dari setiap kasus TB. Angka penularan yang tinggi pada daerah endemik TB disebabkan oleh densitas kasus yang tinggi dan tingginya keterlambatan diagnostik. TB pada anak menggambarkan adanya penularan yang terus berlangsung, anak sering terkena TB pada daerah dimana epidemik orang dewasa sulit dikontrol TB pada anak masih sering diabaikan karena berbagai alasan, seperti kurangnya penelitian ilmiah mengenai TB anak, banyak yang tidak diketahui mengenai akibat terhadap anak dengan TB dan kepercayaan bahwa TB pada anak bukan merupakan faktor penting dalam mengontrol TB (Susanto, 2016).

Berdasarkan jumlah penduduk tahun 2012, diperhitungkan sasaran penemuan kasus baru TB Paru BTA (+) di Provinsi Sumatera Utara adalah sebesar 21.145 jiwa, dan hasil cakupan penemuan kasus baru TB Paru BTA (+) yaitu 17.459 kasus atau 82,57\%. Angka ini mengalami peningkatan bila dibandingkan dengan tahun 2011 yaitu 76,57\% dan 2010 yaitu 68,86\%, oleh Karena itu Sumatera Utara menempati urutan keempat setelah Jawa Barat, Jawa Timur dan Jawa Tengah. (Dinkes Kota Medan, 2013).

Berdasarkan penelitian Sari (2012), di RSUD. H. Adam Malik Medan terdapat 63 anak yang menderita TB Paru, 63,5\% berusia 0-6 tahun. Sedangkan berdasarkan riwayat imunisasi 66,7\% telah mendapat imunisasi BCG dan 33,3\% tidak mendapat imunisasi BCG. Lebih dari 120 juta dosis vaksin BCG diberikan diseluruh dunia setiap tahunnya. Kebanyakan bayi diberi vaksin BCG setelah lahir sesuai dengan rekomendasi WHO, padahal sistem kekebalan tubuh bayi belum dapat menerima vaksin BCG (Ritz, dkk, 2008). 
Penyakit TB Paru dapat dicegah dengan imunisasi yang merupakan tindakan mengakibatkan seseorang mempunyai ketahanan tubuh yang lebih baik sehingga mampu mempertahankan diri terhadap penyakit atau masuknya kuman dari luar. Imunisasi terhadap penyakit TB adalah imunisasi Bacillus Calmette Guerin (BCG) yang telah diwajibkan di beberapa negara dan direkomendasikandi beberapa negara lainnya. Bacillus Calmette-Guerin (BCG), yang telah diwajibkan di 64 negara dan direkomendasikan di beberapa negara lainnya. Indonesia termasuk salah satu negara yang telah melaksanakan vaksinasi BCG sejak tahun 1952 (Murniasih dan Livana, 2007)

Pada tahun 2012 cakupan imunisasi di Indonesia mencapai 99,6\%, sedangkan pada tahun 2013 menurun menjadi 99,3\%, namun jumlah BTA + baru pada usia 0-14 tahun lebih dari 80\%. Imunitas akan timbul 6-8 minggu setelah pemberian BCG. Pemberian BCG pada anak diatas 2 bulan terlebih dahulu harus dilakukan tes Mantoux (tuberkulin), untuk memastikan apakah bayi bebas terhadap penyakit TB. Indonesia memiliki keberhasilan imunisasi yang tinggi, namun masih banyak terdapat anak-anak yang terserang penyakit TB Paru (Kemenkes RI, 2014).

Infeksi TB banyak terjadi pada anak - anak yang sejak semula menghasilkan uji Mantoux positif tetapi tetap dilakukan vaksinasi BCG, sehingga kemungkinan diantara mereka sudah menderita TB sebelum divaksinasi. Kini diakui vaksinasi BCG setidaknya dapat menghindarkan terjadinya TB paru berat pada anak, seperti Tuberculosis milier yang menyebar keseluruh tubuh dan meningitis Tuberculosis yang menyerang otak, yang keduanya bisa menyebabkan kematian pada anak (Depkes RI, 2002).

Menurut (Depkes RI, 2013) cakupan imunisasi dasar di Indonesia tahun 2013 adalah 89,3\% dengan target 2008-2014 adalah 88\%. Hal ini berarti imunisasi dasar di Indonesia sudah cukup tinggi. Di DKI Jakarta, DI Yogyakarta dan Jambi cakupan imunisasi dasar mencapai 100\%, sedangkan di Sumatera Utara cakupan imunisasi dasar masih kurang dari $80 \%$.

Berdasarkan survei awal yang di lakukan di RSU Imelda Pekerja Indonesia Medan pada bulan Januari sampai dengan Desember 2016, dari 504 orang penderita TB paru terdapat $18 \%$ anak usia 1-5 tahun hasil tes tuberculin (Mantoux Test) positif. Dari 18\% tersebut $60 \%$ diantaranya telah mendapatkan imunisasi BCG pada usia kurang dari 1 tahun. Hal ini berarti banyaknya anak yang terdeteksi TB Paru walaupun mereka telah mendapatkan imunisasi BCG.

Berdasarkan uraian diatas menunjukkan tingginya cakupan imunisasi BCG yaitu mencapai $80 \%$ namun angka kejadian TB pada anak juga masih tinggi yaitu sebanyak $18 \%$ dari seluruh penderita TB Paru maka ingin diteliti "Faktor Determinan Kejadian Tuberkulosis Paru Pada Anak Usia 1-5 Tahun Yang Telah Mendapatkan Imunisasi BCG di RSU Imelda Pekerja Indonesia Pekerja Indonesia Medan tahun 2016”.

\section{RESEARCH METHOD}

Jenis penelitian ini adalah unmatched dengan case control. Penelitian ini dilaksanakan di RSU Imelda Medan. Populasi penelitian ini adalah data semua anak yang berumur 1-5 tahun yang telah mendapatkan imunisasi BCG yang memiliki data yang lengkap dan tercantum pada rekam medis di RSU Imelda Medan pada tahun 2016 sebanyak 66 orang. Sampel penelitian ini adalah total populasi dengan menggunakan data anak yang berumur 1-5 tahun pada rekam medis yang menjalani pengobatan di RSU Imelda Medan pada bulan Januari sampai dengan Desember 2016 dengan perbandingan sampel 1:1. Data yang digunakan adalah data sekunder. Data dianalisis menggunakan analisis univariat, dan bivariat dengan uji chi-square pada taraf kepercayaan $95 \%$.

\section{RESULTS AND ANALYSIS}

3.1 Hasil

Berdasarkan hasil penelitian faktor risiko Status gizi, anak yang terinfeksi TB Paru (+) sebagian besar memiliki status gizi tidak normal sebanyak 31 orang $(93,9 \%)$ dan sebagian kecil memiliki status gizi normal sebanyak 2 orang $(6,1 \%)$, sedangkan anak yang terinfeksi TB Paru (-) sebagian besar memiliki status gizi tidak normal sebanyak 24 orang $(72,7 \%)$ dan sebagian kecil memiliki status gizi normal sebanyak 9 orang $(27,3 \%)$.

Hasil uji bivariat menunjukkan bahwa terdapat pengaruh yang signifikan antara status gizi terhadap kejadian TB Paru pada anak usia 1-5 tahun yang telah mendapatkan imunisasi BCG di RSU Imelda Medan tahun 2016, $\mathrm{p}=0,048$, maka $\mathrm{p}<0,05$.

Tabel 1. Pengaruh Status Gizi Terhadap Kejadian TB Paru Pada Anak Usia 1-5 Tahun Yang Telah Mendapatkan Imunisasi BCG Di Rsu Imelda Medan Tahun 2016

\begin{tabular}{lccccccc}
\hline \multirow{2}{*}{ Faktor } & \multicolumn{2}{c}{ TB Paru (+) } & \multicolumn{2}{c}{ TB Paru (-) } & P & OR & 95\%CI \\
\cline { 2 - 6 } & $\mathbf{N}$ & $\boldsymbol{\%}$ & $\mathbf{N}$ & $\mathbf{\%}$ & & & \\
\hline Status Gizi Anak & & & & & & & \\
\hline Tidak Normal & 31 & 93.9 & 24 & 72.7 & \multirow{2}{*}{0,048} & \multirow{2}{*}{5,813} & $1,148-29,436$ \\
\hline Normal & 2 & 6.1 & 9 & 27.3 & & \\
\hline
\end{tabular}




\subsection{Pembahasan}

Berdasarkan hasil penelitian menunjukkan bahwa variabel status gizi sebagian besar anak yang mengalami TB Paru (+) adalah anak yang status gizinya tidak normal sebanyak 31 orang $(93,9 \%)$ dan nilai $p$ $=0,048$, maka $\mathrm{p}<0,05$. Hal ini berarti bahwa terdapathubungan status gizi dengan kejadian TB Paru pada anak usia 1-5 tahun yang telah mendapatkan imunisasi BCG. Dari hasil analisis juga diperoleh nilai OR = $5,813(\mathrm{CI} 95 \%=1,148-29,436)$, Hal ini berarti bahwa responden yang status gizi tidak normal berisiko 5,8 kali lebih besar mengalami TB Paru dibandingkan dengan responden yang status gizi normal.

Hasil penelitian ini sejalan dengan penelitian Kusuma (2011) yang memperoleh hasil bahwa anak yang memiliki status gizi underweight 3,2 kali lebih rentan terkena TB Paru dibandingkan dengan anak yang status gizinya normal. Sama halnya juga dengan penelitian Wiharsini (2012) yang memperoleh hasil anak yang memiliki status gizi underweight 3,2 kali lebih rentan terkena TB paru dibandingkan dengan anak yang status gizinya normal. Gizi buruk muncul akibat ketidakcukupan zat gizi yang berlangsung lama sehingga persediaan/cadangan gizi yang akan digunakan untuk memenuhi ketidakcukupan itu lama-kelamaan akan menjadi kemerosotan jaringan yang ditandai dengan penurunan berat badan, proses ini akan berlanjut sehingga mengakibatkan seseorang menjadi sakit (Supariasa, 2012).

Menurut (Roeswendi, 2009) terdapat hubungan yang bermakna. Dengan nilai $\mathrm{p}=0,01$ dan nilai $\mathrm{OR}=2,36$ (CI 95\% : 1,12-5,30). Hal ini dapat dinterpretasikan bahwa status anak gizi kurang 2,36 kali dapat mengakibatkan terjadinya tuberculosis paru pada anak usia 1-5 tahun di Kabupaten Purworejo Provinsi Jawa Tengah. Penelitian (Muaz, 2014) juga memperoleh hasil yang sama dengan penelitian ini yaitu hasil uji statistik diperoleh nilai $\mathrm{p}=0,001$ artinya $\mathrm{p}<0,05$, sehingga dapat disimpulkan ada hubungan yang bermakna antara status gizi dengan kejadian penderita TB Paru. Selain itu pada penlitian Muaz juga diperoleh OR= 2,513 ( $\mathrm{CI}=1,441-4,382)$, artinya responden yang status gizinya kurang, akan beresiko menderita TB Paru 2,5 kali dibandingkan dengan responden yang status gizinya baik.

Anak yang status gizinya tidak normal atau buruk, akan mengalami gangguan ssstem pertahanan didalam tubuh yang mempermudah anak terserang penyakit infeksi, hal ini karena gizi memiliki manfaat yaitu berperan dalam pertahanan tubuh terhadap penyakit. Penyakit TB Paru lebih banyak terjadi pada anak yang mempunyai gizi buruk sehubungan dengan lemahnya daya tahan tubuh anak yang kurang gizi. TB Paru juga dapat memperburuk status gizi anak (Soeditama, 2002).

Penyakit TB dapat dengan mudah menyerang anak yang mempunyai status gizi yang kurang. Seseorang dengan kondisi kurang gizi akan mempunyai risiko 3,7 kali untuk menderita TB Paru berat dibandingkan dengan orang yang status gizinya normal (Depkes RI, 2001).

Dalam perkembangan dan pertumbuhan fungsi tubuh, anak-anak memerlukan gizi yang cukup. Keadaan gizi anak yang kurang baik akan mempengaruhi perkembangan dan pertumbuhan berbagai fungsi terutama system pertahanan tubuh, sehingga anak akan mudah terserang penyakit. TB dan gizi yang tidak normal sering kali ditemukan secara bersamaan. Infeksi TB menimbulkan penurunan berat badan dan penyusutan tubuh, sedangkan defisiensi gizi akan meningkatkan risiko infeksi karena berkurangnya fungsi daya tahan tubuh terhadap penyakit. Meski tidak semua orang yang terinfeksi basil TB akan menjadi sakit TB. Namun status gizi akan mempengaruhi daya tahan tubuh untuk melawan perkembangan basil TB (kusuma, 2011).

\section{CONCLUSION}

Sebagian besar anak yang menderita TB Paru adalah anak yang memiliki status gizi yang tidak normal dan terdapat pengaruh yang signifikan antara status gizi terhadap kejadian tuberculosis paru pada anak usia 1-5 tahun yang telah mendapatkan imunisasi BCG di RSU Imelda Medan.

\section{REFERENCES}

Achmadi, U., F. (2005). Manajemen Penyakit Berbasis Wilayah. Jakarta: Penerbit Buku Kompas.

Achmadi, U., F. (2008). Manajemen Penyakit Berbasis Wilayah. Jakarta: UPress.

Crofton, J,,Horne, N., Miller, F. (2002). Tuberculosis Klinis. Jakart : Widya Medika.

Depkes RI. (2002). Pedoman Nasional Penanggulangan Tuberkulosis. Jakarta: Depkes

Depkes RI. (2009). Buku Saku Kader Program Penanggulangan TB. Jakarta : Kementrian Kesehatan Republik Indonesia, akses online tanggal 12 Februari 2017, URL : http://www.tbindonesia.or.id/opendir/Buku/buku-saku-tb-revfinal.pdf

Depkes RI. (2013). Petunjuk Teknis Manajemen TB Anak. Akses Online Tanggal 25 Desember 2013. URL : http://www.tbindonesia.or.id/tbidcnt/uploads/2017/02/Buku-Petunjuk-Teknis-Manajemen-danTatalaksana-TB-Anak.pdf.

Depkes RI. (2014). Situasi Imunisasi Indonesia. Akses Online tanggal 19 Februari 2017. URL: http://www.depkes.go.id/ pusdatin/InfoDatin-Imunisasi-2016.pdf.

Dinas Kesehatan provinsi Sulawesi Utara, (2012). Profil kesehatan Sulawesi Utara. Akses Online Tanggal 
19 Februari 2017.URL: http://www.depkes.go.id/ProfilKes.Prov. SulawesiUtara.

Dotulong, J., F., J. (2015). Hubungan Faktor Risiko Umur, Jenis Kelamin Dan Kepadatan Hunian Dengan Kejadian Penyakit TB Paru Di Desa Wori Kecamatan Wori. Akses Online Tanggal 17 Desember 2017. URL : http://C:/Users/ASUS/Documents/tesis/jurnalpdf.

Febrian, M., A., (2015). Faktor-Faktor Yang Berhubungan Dengan Kejadian Tb Paru Anak Di Wilayah Puskesmas Garuda Kota Bandung. Diakses Tanggal 27 November 2017. URL: http://C:/Users/ASUS/Documents/tesis/154-497-1-PB.pdf.

Hasmi. (2016). Metode Penelitian Kesehatan. Jayapura: In Media.

Herman. (2015). TBC Organ Reproduksi Sebabkan Kemandulan. Akses Online tanggal 02 Agustus 2017. URL: $\quad$ http://www.beritasatu.com/kesehatan/249490-tbc-pada-organ-reproduksi-bisa-sebabkankemandulan.html.

IDAI. (2011). Pedoman Imunisasi Di Indonesia 4. Jakarta: IDAI.

Imarruah ,Y. (2014). Hubungan Kejadian Tuberkulosis Paru Pada Anak Dengan Kepatuhan Pemberian Imunisasi BCG di Puskesmas Parongpong Kabupaten Bandung Barat. Akses Online tanggal 18 Januari 2017. URL: journal.respati.ac.id/index.php/ilmukeperawatan/article/download/208/182.

Ink's. (2000). Tuberculosa Pada Anak. Akses Online tanggal 19 Januari 2017. URL : http://documentslide.co m/documents/tb-pada-anak-by-dr-inks.html.

Is giyanto, A. (2009). Teknik Pengambilan Sampel. Jogjakarta: Mitra Cendikia Pres.

Kemenkes. (2014). Pedoman Nasional Pengendalian Tuberkulosis. Jakarta : Kemenkes RI, Akses Online tanggal 23 Maret 2017. URL: http:// www.tbindonesia.or.id.

Lemeshow, S., Hosmer, Jr., Klar, J., and Lwanga. (1990) Adequacy of sample size study in health study. USA ; WHO.

Machfoedz, I. (2009) Metode Penelitian Bidang Kesehatan, Keperawatan, kebidanan, kedokteran. Yogyakarta : Fitramay.

Mahfuzhah, I. (2014). Gambaran Faktor Risiko Penderita Tb Paru Berdasarkan Status Gizi Dan Pendidikan Di Rsud Dokter Soedarso, Akses Online Tanggal 17 November 2017; http://jurnal.untan.ac.id/index.php/jfk/article.

Muaz, F. (2014). Skripsi: Faktor-Faktor Yang Mempengaruhi Kejadian Tuberculosis Paru Basil Tahan Asam Positif Di Puskesmas Wilayah Kecamatan Serang Kota Serang Tahun 2014. Akses online tanggal 08 Desember 2017.

Murniasih, E., dan livina. (2007). Hubungan Pemberian Imunisasi BCG Dengan Kejadian Tuberkulosis Paru Pada Anak Balita Di Balai Pengobatan Penyakit Paru-Paru Ambarawa. Akses Online tanggal18 Januari 2017. URL:http://www.skripsistikes.wordpress.com.

Ngatisyah. (2005). Perawatan Anak Sakit. Jakarta: EGC.

Notoatmodjo, Soekidjo. (2012). Jakarta: Rineka Cipta.

Permenkes No. 42. (2013). Penyelenggraan Imunisasi. Jakarta: Kemenkes RI.

Rab, T. (2010). Ilmu Penyakit Paru. Jakarta: Trans Info Media.

Rachim, R, D, A. (2014). Hubungan Pemberian Imunisasi BCG Dengan Kejadian Tuberculosis Pada Anak Di Puskesmas Pandian Kabupaten Sumenep, Akses Online tanggal 21 Maret 2014. URL: http://ejournal.umm.ac.id/article/viewFile, $10(2): 109-113$.

Kemenkes RI. (2013). Riset Kesehatan Dasar. Jakarta: Kemenkes RI.

Ritz, N., Willem, A., Browne, R, R., Britton, Britton, W, J., Curtis, N. (2008). Influence of BCG Vaccine Strain On The Immune Response And Protection Against Tuberculosis. Akses Online tanggal 20 Maret 2017. URL : https://www.ncbi.nlm.nih.gov/pubmed/18616602 32 (5) : 821-84.

Rosandali, F., Aziz, R., dan Netti, S. (2016). Hubungan Antara Pembentukan Scar Vaksin BCG Dan Kejadian Infeksi Tuberculosi. Akses Online tanggal 14 Mei 2017. URL : http:// jurnal fk.unand.ac.id,6 (1) : 2-1.

Roswendi, A, S. (2009). Faktor Determinan Kejadian TB Paru Pada Anak Di Kabupaten Purworejo Provinsi Jawa Tengah. Akses Online Tanggal 8 desember 2017. URL: http///C:/Users/ASUS/Documents/tesis/Roswendi\%202009.pdf.

Sari, D, A, (2012). Karakteristik Penderita Tuberkulosis Paru Anak Tahun 2012 Di RSUP, Haji Adam Malik Medan. Akses Online tanggal 21 Maret 2013. URL: http:repository,usu,ac,id/bitstream, Tesis.

Susanto, C, K., Wahani, A., Romphis, J. (2012). Hubungan Pemberian Imunisasi Bcg Dengan Kejadian Tb Paru Pada Anak Di Puskesmas Tuminting. Akses Online tanggal 22 Januari 2017. URL: http: /lejournal,unsrat,ac,id, 4 (1) : 1-5.

Villamor, E., Anastasia, I., Chattingius, S. (2010). Evidance For An Effect Of Fetal Growth On The Risk Of Tuberculosis. Akses Online Tanggal 27 November 2017. URL: http:// jid. Oxfordjournals.org/content/full pdf.

Wahyu, G, G. (2008). Panduan Praktis Mencegah dan Menangkal TBC pada Anak. Jakarta: Dian rakyat. 
Werdhani, R, A. (2016). Patofisiologi, Diagnosis, Dan Klafisikasi Tuberkulosis. Akses Online tanggal 11 Januari 2017. URL : http: //www,yumpu,com/patofisiologi-diagnosis-dan-klasifikasi-tuberkulosis.

WHO. (2006). WHO Fachtsheet: TB and Children. Akses Online tanggal 09 April 2017. URL:http://www, Searo, WHO, int,ent,/section10/section2097/section2106_10681, htm.

WHO. (2013). Global Tuberculosis Report. WHO. Akses Online tanggal 09 April 2017. URL : http://apps, who,int/iris/bitstream/10665/91355/1/9789241564656_eng,pdf.

WHO. (2014). Global Tuberculosis Report. Akses Online tanggal 10 April 2017. URL : http://apps,who,int/iris/bitstream/10665/112738/1/9789240692671_eng,pdf.

WHO. (2015). Global Tuberculosis Report. Akses Online tanggal 10 April 2017. http://apps,who,int/iris/bitstream/10665/191102/1/9789241565059_eng,pdf

WHO. (2016). Global Tuberculosis Report, Akses Online tanggal 10 April 2017. URL : http://www.who.int/tb/publications/global_report/gtbr2016_executive_sumary.pdf?ua=1.

\section{BIOGRAPHIES OF AUTHORS}

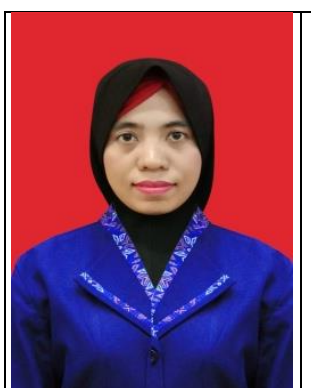

Rahmawani Fauza, Gelar D-III diperoleh dari Akademi Kebidanan Imelda Medan, Jurusan Kebidanan pada tahun 2007. Gelar D-IV diperoleh dari Universitas Sumatera Utara, Jurusan Bidan Pendidik pada tahun 2009. Magister Kesehatan Masyarakat diperoleh dari Universitas Sumatera Utara, Jurusan Kesehatan Masyarakat pada tahun 2018. Saat ini aktif sebagai dosen tetap di Prodi S1 Kebidanan STIKes Imelda Medan.

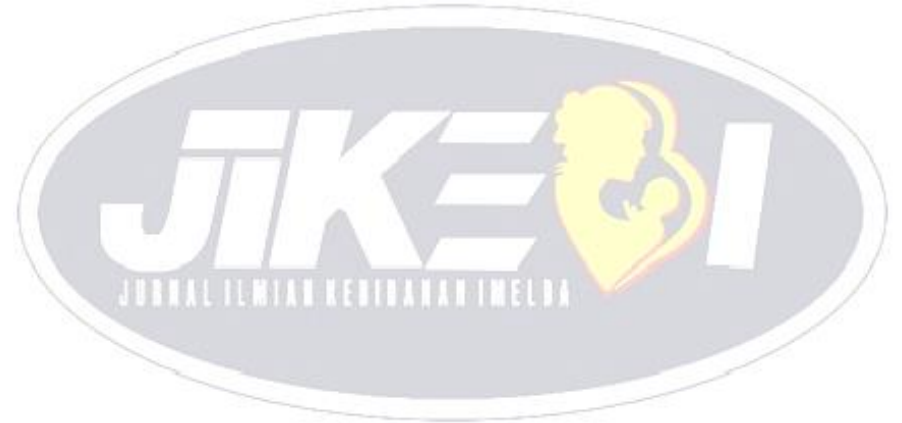

